\title{
No health without mental health-towards a holistic approach
}

Meni Malliori

From $1^{\text {st }}$ International Congress on Neurobiology and Clinical Psychopharmacology and European

Psychiatric Association Conference on Treatment Guidance

Thessaloniki, Greece. 19-22 November 2009

The importance of the promotion and the protection of physical and recently mental health is globally well recognized, but little attention has been given to the interrelationship between the two. Poor physical health can make individuals susceptible to poor mental health. Similarly, we know that people living with mental health problems often live with physical health problems as well. A growing body of evidence is now showing that, indeed, persons with an enduring mental illness are at much greater risk than the general population for developing certain physical health problems, most notably cardiovascular disease, diabetes, obesity. This is the reason why, compared with the general population, people with severe mental illness lose 25-30 years of normal life expectancy.

A holistic, but individualized, approach is proposed which involve, deep knowledge from health professionals about how to deal with co-morbidities, direct communication between doctors and families, careful monitoring of individuals receiving health care interventions and better collaboration among primary care physical and mental health specialists.

Published: 22 April 2010

doi:10.1186/1744-859X-9-S1-S35

Cite this article as: Malliori: No health without mental health-towards

a holistic approach. Annals of General Psychiatry 2010 9(Suppl 1):S35.
Submit your next manuscript to BioMed Central and take full advantage of:

- Convenient online submission

- Thorough peer review

- No space constraints or color figure charges

- Immediate publication on acceptance

- Inclusion in PubMed, CAS, Scopus and Google Scholar

- Research which is freely available for redistribution

Submit your manuscript at www.biomedcentral.com/submit
C Biomed Central 